\title{
Photoperiod and Temperature Influence Flowering Responses and Morphology of Tecoma stans
}

\author{
Ariana P. Torres and Roberto G. Lopez ${ }^{1,2}$ \\ Department of Horticulture and Landscape Architecture, Purdue University, \\ 625 Agriculture Mall Drive, West Lafayette, IN 47907
}

Additional index words. critical daylength, days to flower, yellow trumpet bush, inductive photoperiod

\begin{abstract}
Tecoma stans (L. Juss. Kunth) 'Mayan Gold' is a tropical flowering plant that was selected as a potential new greenhouse crop for its physical appearance and drought and heat tolerance. The objective of this study was to quantify how temperature during the finishing stage and photoperiod during propagation and finishing stages influence growth, flowering, and quality. In Expt. 1, plants were propagated from seed under four photoperiods $(9,12,14$, or $16 \mathrm{~h})$ for 35 days. Under long-day (LD) photoperiods (14 h or greater), seedlings were 3.0 to $3.7 \mathrm{~cm}$ taller than those propagated under 9-h photoperiods. During the finishing stage, days to first open flower, shoot dry mass, and number of nodes below the terminal inflorescence were reduced when plants were grown under LD photoperiods. In addition, number of open flowers and branches increased under LD photoperiods. Few plants developed visible buds when grown under short-day (SD) photoperiods (12 h or less). In Expt. 2, plants were forced at average daily temperatures of 19,20 , or $22{ }^{\circ} \mathrm{C}$ after transplant. Time to first open flower was reduced by 7 days as temperature increased. Inversely, number of visible buds increased by 57 as temperature increased from 19 to $22{ }^{\circ} \mathrm{C}$. Under the experimental conditions tested, the most rapid, complete, and uniform flowering of Tecoma occurred when plants were propagated and finished under LD photoperiods and forced at $22^{\circ} \mathrm{C}$.
\end{abstract}

The yellow trumpet bush (Tecoma stans) is a tree in the Bignoniaceae family that has funnel-shaped, bright yellow, fragrant flowers that compliment its glossy green, pinnate leaves. It is native to the tropical and subtropical regions of Central and South America (Bailey and Bailey, 1976). Tecoma 'Mayan Gold' was selected as a potential new annual flowering crop for patio use as a result of its compact structure, drought and heat tolerance, long-blooming characteristics, and few disease and pest problems (PanAmerican Seed, 2010).

Most U.S. greenhouse growers experience difficulties propagating, growing, and inducing flowering to schedule new crops to meet specific market dates (Davis and Andersen, 1989; Fausey and Cameron, 2005; Pizano, 2005). By determining the environmental requirements (i.e., temperature and light) for flower initiation and development, growers can minimize production time and costs, maximize plant biomass, use greenhouse space

Received for publication 21 Oct. 2010. Accepted for publication 6 Jan. 2011.

We gratefully acknowledge Rob Eddy, Dan Hahn, Chris Currey, and Diane Camberato for greenhouse assistance; funding from the Purdue Agriculture Research Programs Assistantship; and support from the Purdue Agricultural Experiment Station., Ball Horticultural Company, Premiere Horticulture, and The Scotts Co. for seeds, growing media, and fertilizer.

${ }^{1}$ Assistant Professor and Extension Specialist.

${ }^{2}$ To whom reprint requests should be addressed; e-mailrglopez@purdue.edu. more effectively, and increase crop quality (Erwin, 2009; Warner and Erwin, 2003).

Tropical plants of equatorial origin are believed to be more sensitive to small differences in daylength (photoperiod) than those from temperate regions (Sanford, 1974). Plant responses influenced by photoperiod include bud dormancy, formation of storage organs, asexual reproduction, leaf development, stem elongation, germination, flower initiation, and development (Thomas and Vince-Prue, 1984). The classification of plants according to their photoperiodic response is usually made on the basis of flowering and is strongly correlated with flower induction in many ornamental crops (Jackson, 2009; Thomas and Vince-Prue, 1997). Other quantitative factors that may be influenced by photoperiod such as flowering percentage and flower number are important horticulturally, yet botanically they are often not quantified as photoperiodic responses. Furthermore, the critical daylength (CDL) is the photoperiod above or below which the transition to flowering occurs (Jackson, 2009). For example, Currey and Erwin (2010) identified that the CDL for kalanchoe sp. (Kalanchoe glaucescens, $\mathrm{Ka}$ lanchoe manginii, and Kalanchoe uniflora) was $12 \mathrm{~h}$, whereas shorter periods resulted in plants flowering in less time and with fewer nodes below the terminal inflorescence as well as increased flower number. Time to flower and number of nodes below the first open flower are reduced when plants are grown under the appropriate photoperiod, which is species-specific (Currey and Erwin, 2010;
Karlsson and Werner, 2002; Mattson and Erwin, 2003; Rohwer and Heins, 2007; Warner, 2010).

In addition to photoperiod, air temperature influences plant development. The time required for developmental processes to occur (i.e., time to unfold a leaf or to flower) is primarily a function of accumulated thermal energy or degree-days $\left({ }^{\circ} \mathrm{C} \cdot \mathrm{d}^{-1}\right)($ Liu and Heins, 2002). The rate of progress toward a developmental rate is zero at or below a species-specific base temperature $\left(\mathrm{T}_{\mathrm{b}}\right)$ and is maximum at the optimal temperature $\left(\mathrm{T}_{\mathrm{opt}}\right)$ (Roberts and Summerfield, 1987). Between $\mathrm{T}_{\mathrm{b}}$ and $\mathrm{T}_{\mathrm{opt}}$, the rate of development increases with temperature and can be described using a linear relationship.

Characteristics such as leaf unfolding and expansion, plant height, leaf color, number of visible buds and open flowers, and time to flower are reduced when plants are grown at $\mathrm{T}_{\text {opt }}$ (Yuan et al., 1998). Optimal temperature ranges vary between and within species and are associated with their climatic origins (Roberts and Summerfield, 1987). Crop quality can decrease when plants are forced at $\mathrm{T}_{\mathrm{opt}}$ for plant development (Warner, 2010). For example, increasing temperature from 14 to $26^{\circ} \mathrm{C}$ decreased time from visible inflorescence to flower by $43 \mathrm{~d}$ in the pansy orchid (Zygopetalum Redvale 'Fire Kiss'), but flower longevity also decreased (Lopez and Runkle, 2004). In tick seed (Coreopsis grandiflora), shasta daisy (Leucanthemum Xsuperbum), and black-eyedsusan (Rudbeckia fulgida), days to visible bud and anthesis, flower size, flower and bud number, and plant height decreased as temperature increased from 15 to $26{ }^{\circ} \mathrm{C}$ (Yuan et al., 1998). Therefore, information on the time required to reach a developmental stage at various temperatures and its effects on quality are critical to developing production schedules.

To our knowledge, no studies have been published on the effects of photoperiod and temperature during the propagation and/or finishing stage on growth, development, and morphology of Tecoma stans. The objectives of this study were to: 1) determine the photoperiod responses of Tecoma during propagation and finishing stages; and 2) quantify the effects of temperature during the finishing stage.

\section{Materials and Methods}

Plant material. Seeds of Tecoma stans 'Mayan Gold' (PanAmerican Seed, West Chicago, IL) were sown in 72-cell $(44 \mathrm{~mL}$ individual cell volume) plug trays (Root tutor; Summit Plastic, Akron, $\mathrm{OH}$ ) filled with a commercial soilless medium composed of $\approx 70 \%$ Canadian sphagnum peatmoss and $\approx 30 \%$ perlite (Super Fine Germinating Mix; Conrad Fafard, Anderson, SC). Seeds were covered with a thin layer of vermiculite (Sunshine; SunGro Horticulture, Bellevue, WA) to maintain moisture and trays were covered with clear plastic germination lids (Dillen Products, Middlefield, $\mathrm{OH}$ ) to increase relative humidity. Air temperature was maintained at $24{ }^{\circ} \mathrm{C}$ 
and the daily light integral (DLI) was maintained at $10 \pm 3 \mathrm{~mol} \cdot \mathrm{m}^{-2} \cdot \mathrm{d}^{-1}$ during $35 \mathrm{~d}$ of propagation. Plant material was maintained in a glass-glazed greenhouse with exhaust fan and evaporative-pad cooling, radiant hot water, and retractable shade curtains controlled by an environmental computer (Maximizer Precision 10; Priva Computers Inc., Vineland Station, Ontario, Canada) at Purdue University, West Lafayette, IN (lat. $40^{\circ} \mathrm{N}$ ). An automatic woven shade curtain was retracted when the outdoor light intensity reached $\approx 1000 \mu \mathrm{mol} \cdot \mathrm{m}^{-2} \cdot \mathrm{s}^{-1}$ (OLS 50; Ludvig Svensson Inc., Charlotte, NC) throughout the study to prevent leaf scorch.

Photoperiod during propagation and finishing stages (Expt. 1). The experiment was replicated in time beginning on 3 Mar. 2010 and 10 Mar. 2010, and experimental treatments were identical between replications. Seeds were sown under each of four photoperiods: $9,12,14$, or $16 \mathrm{~h}$ of continuous light on a 24-h diurnal cycle. From 0800 to 1600 HR daily, high-pressure sodium (HPS) lamps (HID; PARsource, Petaluma, CA) provided a supplemental photosynthetic photon flux $(P P F)$ of $111 \pm 9.4 \mu \mathrm{mol} \cdot \mathrm{m}^{-2} \cdot \mathrm{s}^{-1}$ at canopy level. Opaque black cloth was pulled over the bench at $1600 \mathrm{HR}$ and opened at $0800 \mathrm{HR}$. Photoperiods consisted of 8-h natural daylengths completed by day extension (DE) lighting $\left(P P F\right.$ of $\approx 2 \mu \mathrm{mol} \cdot \mathrm{m}^{-2} \cdot \mathrm{s}^{-1}$ at canopy level) provided by incandescent (INC) lamps switched on at $1600 \mathrm{HR}$ and switched off at 1700, 2000, 2200, or $2400 \mathrm{HR}$ after each photoperiod was completed.

Ten seedlings per photoperiod treatment were randomly selected and transplanted into 12.7-cm diameter standard, round plastic containers $35 \mathrm{~d}$ after sowing. Containers were filled with a commercial soilless medium composed of $\approx 35 \%$ Canadian sphagnum peat, $\approx 30 \%$ vermiculite, $\approx 25 \%$ pine bark, and $\approx 10 \%$ bark (Metro-Mix 510; SunGro Horticulture, Bellevue, WA). The seedlings were then placed in the same environment in which they had been propagated. Data collection was ended when plants flowered or $84 \mathrm{~d}$ after the plants were placed into each finishing treatment.

Temperature (Expt. 2). On 31 Mar. 2009, 10 seedlings were germinated and transplanted as described previously and placed in three different glass-glazed greenhouse compartments with air temperature set points of 18,20 , or $22^{\circ} \mathrm{C}$. A 16 -h photoperiod ( 0500 to $2100 \mathrm{HR}$ ) was maintained with natural daylengths and DE lighting provided from HPS lamps.

Greenhouse temperature and irradiance. Air temperature and light intensity in each treatment were measured with an enclosed thermocouple and quantum sensor every $20 \mathrm{~s}$ (WatchDog weather station; Spectrum Technologies, Plainfield, IL) positioned above the center of each bench. For Expt. 1, the average daily temperatures (ADT) and DLIs during propagation were $23.1 \pm 0.8^{\circ} \mathrm{C}$ and $24.4 \pm$ $1.5^{\circ} \mathrm{C}$ and 9.3 and $11.3 \mathrm{~mol} \cdot \mathrm{m}^{-2} \cdot \mathrm{d}^{-1}$ for replications 1 and 2, respectively. During the finishing stage, the ADT and DLI were $25.1 \pm 1.5^{\circ} \mathrm{C}$ and $25.4 \pm 1.5^{\circ} \mathrm{C}$ and 12.4 and $12.9 \mathrm{~mol} \cdot \mathrm{m}^{-2} \cdot \mathrm{d}^{-1}$ for replications 1 and 2, respectively. For Expt. 2 , the ADT and DLI in each greenhouse were $19.0 \pm 0.6,20.3 \pm 0.5$, and $22.0 \pm 0.8^{\circ} \mathrm{C}$ and $13.7,13.8$, and $14.1 \mathrm{~mol} \cdot \mathrm{m}^{-2} \cdot \mathrm{d}^{-1}$ for Treatments 1,2 , and 3 , respectively.

Plant culture. In both experiments, plants were irrigated as necessary with acidified water supplemented with $15 \mathrm{~N}-2.2 \mathrm{P}-12.5 \mathrm{~K}$ water-soluble fertilizer to provide the following $\left(\mathrm{mg} \cdot \mathrm{L}^{-1}\right)$ : 100 nitrogen $(\mathrm{N}), 15$ phosphorus $(\mathrm{P}), 84$ potassium $(\mathrm{K}), 34$ calcium $(\mathrm{Ca}), 14$ magnesium $(\mathrm{Mg}), 0.5$ iron $(\mathrm{Fe}), 0.3$ manganese $(\mathrm{Mn})$ and zinc $(\mathrm{Zn}), 0.1$ boron $(\mathrm{B})$ and copper $(\mathrm{Cu})$, and 0.05 molybdenum (Mo) during propagation and $200 \mathrm{~N}, 29 \mathrm{P}, 167 \mathrm{~K}$, $67 \mathrm{Ca}, 28 \mathrm{Mg}, 1.0 \mathrm{Fe}, 0.5 \mathrm{Mn}$ and $\mathrm{Zn}, 0.2 \mathrm{~B}$ and $\mathrm{Cu}$, and $0.1 \mathrm{Mo}$ during the finishing stage (Peters Excel@ Cal-Mag@ 15N-2.2P-12.5K; The Scotts Co., Marysville, OH). Irrigation water was supplemented with $93 \%$ sulfuric acid (Ulrich Chemical, Indianapolis, IN) at $0.08 \mathrm{~mL} \cdot \mathrm{L}^{-1}$ to reduce alkalinity to $100 \mathrm{mg} \cdot \mathrm{L}^{-1}$ and $\mathrm{pH}$ to a range of 5.7 to 6.0 .

Data collection and analysis. For Expt. 1, 10 seedlings per photoperiod treatment and per replication were randomly selected for harvest $35 \mathrm{~d}$ after sowing. Height and number of nodes were measured at harvest. The rooting medium was carefully washed off and roots, leaves, and stem were separated and shoot dry weight (SDW) and root dry weight (RDW) were recorded after drying in an oven at $70{ }^{\circ} \mathrm{C}$ for $7 \mathrm{~d}$.

Days to visible bud and to first open flower, height, and node number below the terminal inflorescence; total plant height (height from the medium to the top of the inflorescence); number of visible buds $5 \mathrm{~mm}$ or greater; number of flowers with fully reflexed petals (open flowers); branches; and inflorescences were recorded. Internode length was calculated by dividing the height below the terminal inflorescence by node number below terminal inflorescence. Relative growth in terms stem elongation was calculated as the relation of total height and number of days to first open flower. SDW gain rate was determined as the relation of SDW and number of days to first flower and it was used to express relative growth rate in terms of aboveground biomass accumulation per day. The percentage of the population that had visible buds or had flowered after $84 \mathrm{~d}$ was calculated by dividing the number of flowering plants in each treatment by the total number of plants in a treatment. The experiment was repeated in time and completely randomized with four treatments $(9,12,14$, and $16 \mathrm{~h})$ and 10 samples (indi-

Table 1. Influence of photoperiod during the propagation stage of Tecoma stans on height, number of nodes, shoot dry weight (SDW), and root dry weight (RDW) $35 \mathrm{~d}$ after sowing. ${ }^{\mathrm{z}}$

\begin{tabular}{lcccc}
\hline Photoperiod $(\mathrm{h})$ & $\mathrm{Ht}(\mathrm{cm})$ & Node $($ no. $)$ & SDW $(\mathrm{mg})$ & RDW $(\mathrm{mg})$ \\
\hline 9 & $4.2 \mathrm{~d}^{\mathrm{y}}$ & $2.8 \mathrm{c}$ & $77.1 \mathrm{a}$ & $19.5 \mathrm{a}$ \\
12 & $5.9 \mathrm{c}$ & $3.5 \mathrm{ab}$ & $132.4 \mathrm{a}$ & $18.4 \mathrm{a}$ \\
14 & $7.9 \mathrm{a}$ & $3.9 \mathrm{a}$ & $122.0 \mathrm{a}$ & $24.3 \mathrm{a}$ \\
16 & $7.2 \mathrm{~b}$ & $3.4 \mathrm{~b}$ & $99.9 \mathrm{a}$ & $20.0 \mathrm{a}$ \\
$P$ value $^{\mathrm{x}}$ & 0.001 & 0.001 & 0.344 & 0.019 \\
\hline
\end{tabular}

${ }^{\mathrm{z}}$ Data were pooled for replications 1 and $2(\mathrm{n}=20)$.

${ }^{y}$ Any two means within a column not followed by the same letter are significantly different at $P \leq 0.05$ based on Tukey's honestly significant difference test.

${ }^{\mathrm{x}}$ Significance of mean differences within a category based on analysis of variance. vidual plants) per treatment. Data were pooled for replications 1 and 2 . Therefore, there were four treatments and two replications with a total of 80 plants. Data were analyzed using the PROC GLM procedure in SAS (Version 9.1; SAS Institute, Cary, NC). Analyses of variance (ANOVA) and mean separation by Tukey's honestly significant difference (HSD) $(P \leq 0.05)$ were performed for all data. Percentage data were arcsin transformed before ANOVA. Non-flowering plants were not included in the analyses other than to calculate the percentage of plants that flowered.

For Expt. 2, days to visible bud and first inflorescences and SDW and RDW were recorded. Data collection was ended when all the plants flowered. The experimental sign was completely randomized with three temperatures $\left(18,20\right.$, or $\left.22{ }^{\circ} \mathrm{C}\right)$ and 20 replicates per treatment. Therefore, there were three treatments and 20 plants for a total of 60 plants. Data were analyzed using the PROC GLM procedure in SAS (Version 9.1; SAS Institute). ANOVA and mean separation by Tukey's HSD $(P \leq 0.05)$ were performed for all data.

Photoperiod during propagation and finishing stage (Expt.1). Photoperiod significantly $(P \leq 0.001)$ influenced height and number of nodes of Tecoma seedlings when after $35 \mathrm{~d}$ of propagation (Table 1 ). For example, height and node number of seedlings increased from 4.2 to $7.2 \mathrm{~cm}$ and 2.8 to 3.4 nodes as photoperiod increased from 9 to $16 \mathrm{~h}$. Photoperiod had no significant effect on SDW or RDW. For example, RDW of seedlings grown under 9-, 12-, 14-, or 16-h photoperiods was $19.5,18.4,24.3$, and $20.0 \mathrm{mg}$, respectively (Table 1 ).

Time to visible bud was hastened by $40 \mathrm{~d}$ as photoperiod increased from 9 to $16 \mathrm{~h}$. Photoperiod significantly $(P \leq 0.001)$ affected the percentage of plants that had visible buds and flowers after $84 \mathrm{~d}$ (Table 2). For example, under the 9-h photoperiod, only one plant per replication had visible buds, and no plant flowered after $84 \mathrm{~d}$; therefore, developmental and growth data were not collected (Table 2). Only 30\% of Tecoma plants flowered when placed under a 12-h photoperiod during finishing. All plants flowered under 14- or 16-h photoperiods (Table 2). As daylength increased from 12 to $16 \mathrm{~h}$, days to first open flower decreased by $11 \mathrm{~d}$. At open flower, total plant height, number of visible buds, flowers, lateral branches, and 
first open flower, the number of inflorescences, visible buds, and open flowers significantly increased $(P \leq 0.001)$ as photoperiod increased from 12 to $16 \mathrm{~h}$.

Photoperiod had a significant effect on stem elongation, number of branches and nodes below the terminal inflorescence, internode length, SDW, and SDW gain rate (Table $2)$. For example, stem elongation increased $(P \leq 0.003)$ by $38 \%$ as photoperiod increased from 12 to $16 \mathrm{~h}$. Node number below the terminal inflorescence decreased from 12.4 to 10.6 nodes and internode length increased by $50 \%$ as photoperiod increased from 12 to $16 \mathrm{~h}$. As photoperiod increased from 12 to $16 \mathrm{~h}$, branch number, SDW, and SDW gain rate increased from 2.0 to $2.8,3.5$ to $5.0 \mathrm{~g}$, and 52.6 to $92.1 \mathrm{mg} \cdot \mathrm{d}^{-1}$, respectively.

Temperature during the finishing stage (Expt.2). Temperature had no influence on days to visible bud ( $P \leq 0.448$; Table 3 ). However, as temperature increased from 19 to $22{ }^{\circ} \mathrm{C}$, days to first open flower decreased by $7 \mathrm{~d}$. At first open flower, the number of visible buds and open flowers increased by 57 and one, respectively, as temperature increased from 19 to $22^{\circ} \mathrm{C}$.

Plant height increased by $20 \mathrm{~cm}$ and the number of branches decreased by four as temperature increased (Table 3). SDW and RDW increased from 3.6 to $5.4 \mathrm{~g}$ and 1.5 to $1.8 \mathrm{~g}$, respectively, as temperature increased from 19 to $22{ }^{\circ} \mathrm{C}$.

\section{Discussion}

After $35 \mathrm{~d}$ of propagation under LD photoperiods (14 h or greater), Tecoma seedlings were $3.0 \mathrm{~cm}$ taller and had more nodes than seedlings propagated under a $9-\mathrm{h}$ photoperiod
(Table 1). However, there was no significant difference in biomass accumulation (i.e., SDW and RDW) across photoperiods. According to Thomas and Vince-Prue (1997), LD plants require light in both the red (R; 600 to $700 \mathrm{~nm}$ ) and far-red (FR; 700 to $800 \mathrm{~nm}$ ) portion of the spectrum for flower induction. In our study, we created LD by growing plants under 8-h natural daylengths followed by DE lighting from INC lamps, which have a low R-to-FR ratio. Stem elongation is promoted and lateral branch development is suppressed when plants are grown under light with a low R-to-FR ratio (Whitman et al., 1998). Therefore, the height increase of Tecoma seedlings under LD can be attributed to longer exposure to FR light as photoperiod increased from 9 to $16 \mathrm{~h}$.

During the finishing stage, plants grown under a 12 -h photoperiod were $5.8 \mathrm{~cm}$ shorter than plants grown under the 16-h treatment. Similarly, Kuehny et al. (2005) reported that ornamental gingers [(Curcuma alismatifolia sp.) 'Precious Patuma', Curcuma parviflora 'White Angel', Curcuma petiolata, and Curcuma cordata] were significantly taller when plants were grown under photoperiods $12 \mathrm{~h}$ or greater created with DE lighting from INC lamps.

As photoperiod increased from 12 to $16 \mathrm{~h}$, days to first open flower significantly decreased $(P \leq 0.001)$ by $11 \mathrm{~d}$. Karlsson and Werner (2002) reported that German primrose (Primula obconica 'Libre Light Salmon') grown under a 16-h photoperiod flowered $11 \mathrm{~d}$ faster than plants under an 8-h photoperiod. Similarly, Warner (2010) found that petunia sp. [Petunia axillaris (Lam.) Britton et al., Petunia exserta Stehmann, Petunia integrifolia (Hook.) Schinz \& Thell., and Petunia $\times$ hybrida Vilm.] grown under LD (9-h photoperiod and a night interruption from 2200 to $0200 \mathrm{HR}$ ) flowered $35,11,12$, and $22 \mathrm{~d}$ earlier, respectively, when compared with plants grown under SD (9-h photoperiod).

Crops can be classified into three main categories based on their flowering response to photoperiod: short-day plants, which require photoperiods at or below CDL; longday plants, which require photoperiods at or above the CDL to obtain the response; and day-neutral plants, which are not induced in response to any photoperiod (Erwin, 2009; Jackson, 2009; Thomas and Vince-Prue, 1997). Common groups also include the subclassification of facultative LD or SD plants (a given photoperiod hastens flowering) and obligate $\mathrm{LD}$ or SD plants (a given photoperiod is strictly required to induce flowering).

Numerous studies have shown the importance of providing inductive photoperiods to increase the flowering percentage in ornamental crops (Currey and Erwin, 2010; Karlsson and Werner, 2002; Mattson and Erwin, 2003; Rohwer and Heins, 2007; Runkle et al., 1999; Warner, 2010). For example, Currey and Erwin (2010) reported that Kalanchoe spp. reached $100 \%$ flowering when plants were grown under 12-h or less photoperiods. In our study, nearly all plants grown under 9-h photoperiods remained vegetative and only $30 \%$ of plants flowered under $12 \mathrm{~h}$. The percentage of plants that had visible buds and flowered was greatest $(100 \%)$ at 14 - and 16 -h photoperiods.

Runkle et al. (1999) reported that the number of nodes below the first inflorescence in black-eyed-susan (Rudbeckia fulgida var. sullivantii 'Goldsturm') decreased from 19.7 to 15.6 as the photoperiod increased from 14 to $24 \mathrm{~h}$. Our data were in agreement, because plants under inductive 16-h photoperiods

Table 2. Influence of photoperiod during the finishing stage on Tecoma stans visible bud and flowering percentage, days to visible bud and first open flower, total height, stem elongation, internode length, number of nodes below terminal inflorescence, number of open flowers, number of branches, number of visible buds, number of inflorescences, shoot dry weight, and shoot dry weight gain rate at first open flower. ${ }^{2}$

\begin{tabular}{|c|c|c|c|c|c|c|c|c|c|c|c|c|c|c|}
\hline $\begin{array}{l}\text { Photoperiod } \\
\text { (h) }\end{array}$ & $\begin{array}{l}\text { Days to } \\
\text { visible } \\
\text { bud }\end{array}$ & $\begin{array}{l}\text { Percent } \\
\text { visible } \\
\text { bud }^{\mathrm{y}}\end{array}$ & $\begin{array}{l}\text { Visible } \\
\text { bud } \\
\text { (no.) }\end{array}$ & $\begin{array}{l}\text { Days to } \\
\text { first open } \\
\text { flower }\end{array}$ & $\begin{array}{c}\text { Percent } \\
\text { flowering }\end{array}$ & $\begin{array}{c}\text { Open } \\
\text { flower } \\
\text { (no.) }\end{array}$ & $\begin{array}{c}\text { Inflorescence } \\
\text { (no.) }\end{array}$ & $\begin{array}{c}\text { Total } \\
\text { ht } \\
(\mathrm{cm})\end{array}$ & $\begin{array}{c}\text { Stem } \\
\text { elongation } \\
\left(\mathrm{cm} \cdot \mathrm{d}^{-1}\right)\end{array}$ & $\begin{array}{l}\text { Node } \\
\text { (no.) }\end{array}$ & $\begin{array}{c}\text { Internode } \\
\text { length } \\
(\mathrm{cm} / \text { node })\end{array}$ & $\begin{array}{c}\text { Branch } \\
\text { (no.) }\end{array}$ & $\begin{array}{l}\text { SDW } \\
(\mathrm{g})\end{array}$ & $\begin{array}{c}\text { SDW } \\
\text { gain rate } \\
\left(\mathrm{mg} \cdot \mathrm{d}^{-1}\right)\end{array}$ \\
\hline 9 & $73.5 \mathrm{a}^{\mathrm{x}}$ & $10 \mathrm{c}$ & $-^{w}$ & - & $0 \mathrm{c}$ & - & - & - & - & - & - & - & - & - \\
\hline 12 & $56.5 \mathrm{~b}$ & $50 \mathrm{~b}$ & $50.0 \mathrm{~b}$ & $64.6 \mathrm{a}$ & $30 \mathrm{~b}$ & $0.8 \mathrm{~b}$ & $2 \mathrm{~b}$ & $38.8 \mathrm{a}$ & $0.60 \mathrm{~b}$ & $12.4 \mathrm{a}$ & $1.8 \mathrm{~b}$ & $2.0 \mathrm{~b}$ & $3.5 \mathrm{~b}$ & $52.6 \mathrm{~b}$ \\
\hline 14 & $33.4 \mathrm{c}$ & $100 \mathrm{a}$ & $68.9 \mathrm{ab}$ & $51.0 \mathrm{~b}$ & $100 \mathrm{a}$ & $2.6 \mathrm{a}$ & $3.8 \mathrm{~b}$ & $40.9 \mathrm{a}$ & $0.81 \mathrm{a}$ & $9.9 \mathrm{~b}$ & $2.7 \mathrm{a}$ & $1.9 \mathrm{~b}$ & $4.3 \mathrm{ab}$ & $84.4 \mathrm{a}$ \\
\hline 16 & $36.1 \mathrm{c}$ & $100 \mathrm{a}$ & $80.6 \mathrm{a}$ & $53.9 \mathrm{~b}$ & $100 \mathrm{a}$ & $3.0 \mathrm{a}$ & $5.0 \mathrm{a}$ & $44.6 \mathrm{a}$ & $0.83 \mathrm{a}$ & $10.6 \mathrm{~b}$ & $2.7 \mathrm{a}$ & $2.9 \mathrm{a}$ & $5.0 \mathrm{a}$ & $92.1 \mathrm{a}$ \\
\hline$P$ value $^{\mathrm{v}}$ & 0.001 & 0.001 & 0.016 & 0.001 & 0.001 & 0.001 & 0.001 & 0.151 & 0.003 & 0.001 & 0.033 & 0.001 & 0.006 & 0.001 \\
\hline
\end{tabular}

${ }^{\mathrm{z} D a t a}$ were pooled for replications 1 and $2(\mathrm{n}=20)$.

${ }^{y}$ Visible bud and flowering percentage data were arcsin transformed before analysis of variance.

xAny two means within a column not followed by the same letter are significantly different at $P \leq 0.05$ based on Tukey's honestly significant difference test.

windicates plants did not flower after $84 \mathrm{~d}$ after transplant.

vignificance of mean differences based on analysis of variance.

$\mathrm{SDW}=$ shoot dry weight.

Table 3. Influence of finish average daily temperatures on days to visible bud and flower from transplant, height, number of visible buds, number of visible flowers, number of inflorescences, number of branches, and shoot and root dry weight at first open flower in Tecoma stans $(\mathrm{n}=20)$.

\begin{tabular}{|c|c|c|c|c|c|c|c|c|c|}
\hline $\begin{array}{l}\text { Finish } \\
\text { temp }\left({ }^{\circ} \mathrm{C}\right)\end{array}$ & $\begin{array}{c}\text { Days to } \\
\text { visible bud }\end{array}$ & $\begin{array}{l}\text { Days to first } \\
\text { open flower }\end{array}$ & $\begin{array}{c}\text { Visible bud } \\
\text { (no.) }\end{array}$ & $\begin{array}{c}\text { Open flower } \\
\text { (no.) }\end{array}$ & $\begin{array}{c}\text { Inflorescence } \\
\text { (no.) }\end{array}$ & $\begin{array}{c}\mathrm{Ht} \\
(\mathrm{cm})\end{array}$ & $\begin{array}{c}\text { Branch } \\
\text { (no.) }\end{array}$ & $\begin{array}{c}\text { SDW } \\
(\mathrm{g})\end{array}$ & $\begin{array}{c}\text { RDW } \\
(\mathrm{g})\end{array}$ \\
\hline 19.0 & $18 \mathrm{a}^{\mathrm{z}}$ & $48 \mathrm{a}$ & $20.8 \mathrm{~b}$ & $2.5 \mathrm{~b}$ & $6.0 \mathrm{a}$ & $19.4 \mathrm{c}$ & $6.6 \mathrm{a}$ & $3.6 \mathrm{~b}$ & $1.5 \mathrm{ab}$ \\
\hline 20.3 & $18 \mathrm{a}$ & $45 \mathrm{~b}$ & $30.0 \mathrm{~b}$ & $2.7 \mathrm{~b}$ & $6.3 \mathrm{a}$ & $25.2 \mathrm{~b}$ & $5.0 \mathrm{a}$ & $4.5 \mathrm{ab}$ & $1.4 \mathrm{~b}$ \\
\hline 22.0 & $17 \mathrm{a}$ & $41 \mathrm{c}$ & $77.6 \mathrm{a}$ & $3.8 \mathrm{a}$ & $4.2 \mathrm{a}$ & $39.2 \mathrm{a}$ & $2.2 \mathrm{~b}$ & $5.4 \mathrm{a}$ & $1.8 \mathrm{a}$ \\
\hline$P$ value ${ }^{\mathrm{y}}$ & 0.448 & 0.001 & 0.001 & 0.006 & 0.043 & 0.001 & 0.001 & 0.002 & 0.019 \\
\hline
\end{tabular}

${ }^{\mathrm{z}}$ Any two means within a column not followed by the same letter are significantly different at $P \leq 0.05$ based on Tukey's honestly significant difference test. ${ }^{\mathrm{y}}$ Significance of mean differences based on analysis of variance.

$\mathrm{SDW}=$ shoot dry weight; RDW = root dry weight. 
developed 1.8 fewer nodes below the terminal inflorescence than plants grown under $12 \mathrm{~h}$ (Table 2). This may be because as daylength increases above the CDL for some LD plants, flowering is hastened, resulting in fewer nodes developing below the first flower/inflorescence.

According to Currey and Erwin (2010), to promote complete flowering while minimizing nodes below the first flower/inflorescence, days to flowering, and maximizing flower number, growers should provide the photoperiod, or "horticultural" CDL, at which this occurs. Our findings illustrate that the CDL for Tecoma stans would be at least $14 \mathrm{~h}$ because the most rapid, complete, and uniform flowering occurred when plants were grown under $14 \mathrm{~h}$ or greater. Plants grown under 9- and 12-h photoperiods were short and generally of poor quality. Therefore, we can conclude that Tecoma stans 'Mayan Gold' is a facultative LD plant because flowering occurs faster under LD; plants will eventually develop flower buds if grown under short days.

Tecoma plants finished at warmer temperatures accumulated more biomass (i.e., SDW and RDW) than at cooler temperatures (Table 3 ). This response is similar to other tropical species such as summer snapdragon (Angelonia angustifolia Benth. 'Angel Mist' Series); SDW increased from 4.6 to $9.3 \mathrm{~g}$ as temperature increased from 15 to $30{ }^{\circ} \mathrm{C}$ (Miller and Armitage, 2002).

During commercial production, the ability to control flowering by manipulating the environment is desirable. It allows growers to schedule and improve efficiency and productivity (Blanchard and Runkle, 2008). Although temperature did not affect days to visible bud, it significantly influenced $(P \leq 0.001)$ the number of visible buds and open flowers and days to flower. For example, as temperature increased from 19 to $22{ }^{\circ} \mathrm{C}$, plants flowered $7 \mathrm{~d}$ faster (Table 3 ). In addition, the number of visible buds increased by 57 as temperature increased from 19 to $22^{\circ} \mathrm{C}$ (Table 3 ).

Although we did not determine $\mathrm{T}_{\mathrm{b}}$ or $\mathrm{T}_{\mathrm{opt}}$ for Tecoma, all plants in this experiment flowered when forced at 19 to $22{ }^{\circ} \mathrm{C}$. The highest quality plants were obtained when the finishing stage temperature was maintained $20{ }^{\circ} \mathrm{C}$ or greater. However, plants finished at $19^{\circ} \mathrm{C}$ produced 4.4 more lateral branches than those finished at $22{ }^{\circ} \mathrm{C}$. Typically, flower quality of floriculture crops (i.e., flower size, color, and longevity) and not growth decreased with increasing temperature.

Collectively, these studies suggest that Tecoma stans should be finished at temperatures $20{ }^{\circ} \mathrm{C}$ or greater to avoid flower-bud abortion at cooler temperatures and improve flowering characteristics. Our data also indicate that greenhouse growers should propagate seedlings and finish plants under LD photoperiods (14 h or greater) to obtain highquality transplants and rapid, uniform, and complete flowering.

\section{Literature Cited}

Bailey, L.H. and E.Z. Bailey. 1976. Hortus third: A concise dictionary of plants cultivated in the United States and Canada. Macmillan Publishing Co., New York.

Blanchard, M.G. and E.S. Runkle. 2008. Temperature and pseudobulb size influence flowering of Odontioda orchids. HortScience 43:1404 1409.

Currey, C.J. and J.E. Erwin. 2010. Variation among Kalanchoe species in their flowering responses to photoperiod and short-day cycle number. J. Hort. Sci. Biotechnol. 85:350-354.

Davis, T.D. and A.S. Andersen. 1989. Growth retardants as aids in adapting new floricultural crops to pot culture. Acta Hort. 252:77-86.

Erwin, J.E. 2009. Looking for new ornamentals: Flowering studies. Acta Hort. 813:61-66.

Fausey, B.A. and A.C. Cameron. 2005. Evaluating herbaceous perennial species as new flowering potted crops. Acta Hort. 683:207-213.

Jackson, S.D. 2009. Plant responses to photoperiod. New Phytol. 181:517-531.

Karlsson, M.G. and J.W. Werner. 2002. Photoperiod and temperature affect flowering in german primrose. HortTechnology 12:217-219.

Kuehny, J.S., M. Sarmiento, M.P. Paz, and P.C. Branch. 2005. Effect of light intensity, photoperiod and plant growth retardants on production of zingiberacea as pot plants. Acta Hort. 683:145-154.

Liu, B. and R. Heins. 2002. Photothermal ratio affects plant quality in 'Freedom' poinsettia. J. Amer. Soc. Hort. Sci. 127:20-26.

Lopez, R.G. and E.S. Runkle. 2004. The effect of temperature on leaf and flower development and flower longevity of Zygopetalum Redvale 'Fire Kiss' orchid. HortScience 39:1630-1634.

Mattson, N.S. and J.E. Erwin. 2003. Temperature affects flower initiation and development rate of Impatiens, Petunia, and Viola. Acta Hort. 624:191-197.

Miller, A. and A.M. Armitage. 2002. Temperature, irradiance, photoperiod, and growth retardants influence greenhouse production of Angelonia angustifolia Benth. Angel Mist Series. HortScience 37:319-321

PanAmerican Seed. 2010. Grower facts: Tecoma Mayan Gold. Ball Horticultural Company. 15 June 2010. <http://www.panamseed.com/plant info.aspx?phid=084100001021159>.

Pizano, M. 2005. International market trendsTropical flowers. Acta Hort. 683:79-86.

Roberts, E. and R. Summerfield. 1987. Measurement and prediction of flowering in annual crops, p. L7-51. In: Atherton, J.G. (ed.). Manipulation of flowering. Butterworths, London, UK.

Rohwer, C.L. and R.D. Heins. 2007. Daily light integral, prevernalization, photoperiod, and vernalization temperature and duration control flowering of easter cactus. HortScience 42 : 1596-1604.

Runkle, E.S., R.D. Heins, A.C. Cameron, and W.H. Carlson. 1999. Photoperiod and cold treatment regulate flowering of Rudbeckia fulgida 'Goldsturm'. HortScience 34:55-58.

Sanford, W.W. 1974. The ecology of orchids, p. 123-132. In: Withner, C.L. (ed.). The orchids: Scientific studies. John Wiley and Sons, New York, NY.

Thomas, B. and D. Vince-Prue. 1984. Juvenility, photoperiodism, and vernalization, p. 408-439. In: Wilkins, M.B. (ed.). Advanced plant physiology. Longman Scientific \& Technical, Essex, UK.

Thomas, B. and D. Vince-Prue. 1997. Photoperiodic control of flower initiation: Some general principles, p. 3-28. In: Photoperiodism in plants. 2nd Ed. Academic Press, San Diego, CA.

Warner, R. and J.E. Erwin. 2003. Effect of photoperiod and daily light integral on flowering in five Hibiscus L. spp. Sci. Hort. 97:341-351.

Warner, R.M. 2010. Temperature and photoperiod influence flowering and morphology of four petunia spp. HortScience 45:365-368.

Whitman, C.M., R.D. Heins, A.C. Cameron, and W.H. Carlson. 1998. Lamp type and irradiance level for daylength extensions influence flowering of Campanula carpatica 'Blue Clips', Coreopsis grandiflora 'Early Sunrise', and $\mathrm{Co}$ reopsis verticillata 'Moonbeam'. J. Amer. Soc. Hort. Sci. 123:802-807.

Yuan, M., W.H. Carlson, R.D. Heins, and A.C. Cameron. 1998. Effect of forcing temperature on time to flower of Coreopsis grandiflora, Leucanthemum Xsuperbum, Leucanthemum Xsuperbum and Rudbeckia fulgida. HortScience 33:663-667. 